\title{
PENGARUH LITERASI EKONOMI DAN MODERNITAS TERHADAP PERILAKU KONSUMTIF MAHASISWA
}

\author{
Ivo Selvia Agusti ${ }^{\left.{ }^{*}\right)}$ Nining Dewanti Gultom ${ }^{2)}$ \\ ${ }^{1)}$ Pendidikan Bisnis Fakultas Ekonomi Universitas Negeri Medan \\ ${ }^{2)}$ Mahasiswa Pendidikan Bisnis Universitas Negeri Medan \\ E-mail: unimedivo@yahoo.co.id
}

\begin{abstract}
Masalah penelitian adalah bagaimana perilaku konsumsi mahasiswa. Tujuan penelitian untuk mengetahui seberapa besar pengaruh literasi ekonomi dan modernitas terhadap perilaku konsumtif mahasiswa. Risnawati, et al (2018: 431) Terkait dengan perubahan perilaku konsumsi yang terjadi terhadap perilaku konsumtif, literasi ekonomi dianggap sangat penting dalam meningkatkan kompetensi masing-masing individu untuk membuat keputusan pribadi dan sosial tentang banyak masalah ekonomi yang akan dihadapi sepanjang masa hidupnya. Penelitian dilakukan di Fakultas Ekonomi Universitas Negeri Medan dengan jumlah populasi dan sampel adalah 90 orang. Uji instrumen penelitian menggunakan uji validitas dan reliabilitas dengan SPSS. Teknik analisis data penelitian yang digunakan: uji normalitas, uji linieritas, uji multikolinieritas, linier berganda, koefisien determinasi, uji t dan uji f menggunakan aplikasi SPSS 25 for windows. Hasil uji F menunjukkan bahwa literasi ekonomi dan modernitas berpengaruh negatif dan signifikan terhadap perilaku konsumtif dengan Fhitung 7,024> Ftabel3,10 dengan nilai signifikansi 0,001 $<0,05$. Hasil perhitungan regresi linier berganda adalah $\mathrm{Y}=156,609+(-0,615) \mathrm{X} 1+(-0,625) \mathrm{X} 2$ dengan koefisien determinasi adalah 13,9\%. Diskusi penelitian Rosida (2018: 224) bahwa modernitas dan literasi ekonomi adalah dua hal yang sama-sama memprioritaskan ide rasionalitas, sehingga ketika siswa memiliki modernitas dan literasi ekonomi yang baik, mereka harus dapat membantu siswa mempertimbangkan dan membandingkan berbagai hal. dibutuhkan atau diinginkan melalui teknologi yang ada dan berdasarkan pada pemahaman ekonomi bahwa siswa; miliki sehingga siswa dapat berperilaku rasional
\end{abstract}

Kata Kunci : Literasi Ekonomi, Modernitas, Perilaku Konsumsi . 


\section{PENDAHULUAN}

Risnawati, dkk (2018:430) menyatakan bahwa: "Proses pembentukan perilaku konsumsi yang rasional dalam diri seseorang merupakan fungsi dari seluruh potensi (kognisi, efeksi, dan psikomotor) dalam konteks interaksi dengan lingkungan sosial (dalam keluarga, sekolah, dan masyarakat) berlangsung sepanjang hayat. Mahasiswa adalah bagian dari masyarakat yang tidak lepas dari perilaku konsumsi. Angra, dkk (2018 : 145) menyatakan bahwa "Kampus yang seharusnya merupakan tempat mahasiswi memperoleh ilmu pengetahuan namun yang terlihat kampus dijadikan ajang pamer. Mahasiswi yang seharusnya bisa berfikir secara rasional dalam memenuhi kebutuhan".Berikut hasil observasi dari angket pra-penelitiaan yang dilakukan oleh peneliti, yang dibagikan kepada 35 orang mahasiswa prodi Pendidikan Bisnis Fakutas Ekonomi Universitas Negeri Medan angkatan 2017. Diagram 1

\section{Hasil Angket Perilaku Konsumtif Mahasiswa Prodi Pendidikan Bisnis Angkatan 2017}

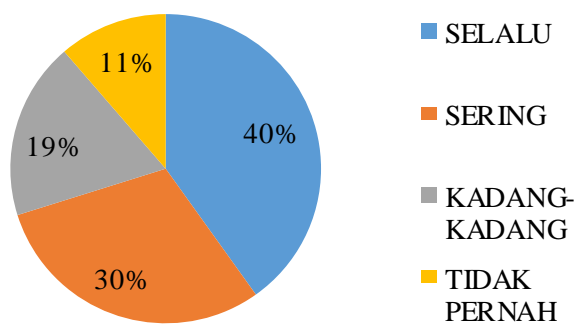

Sumber :Data yang diolah dari angket

Dari diagram di atas, dapat kita lihat bahwa perilaku konsumtif mahasiswa prodi Pendidikan Bisnis Fakutas Ekonomi Universitas Negeri Medan angkatan 2017 dikatakan tinggi dimana persentase tertinggi terdapat pada pilihan "Selalu"sebanyak 40\% dan "Sering" sebanyak $30 \%$. mahasiswa lebih mementingkan tren dan gengsi.

Nur dan Syamsudin (2018:17-18) bahwa "literasi ekonomi merupakan alat yang berguna untuk merubah perilaku dari tidak cerdas menjadi cerdas, ilmu ekonomi terbagi dalam dua bagian besar yang kelak akan menurunkan ilmuilmu ekonomi teori dan terapan, yaitu ilmu ekonomi mikro dan ilmu ekonomi makro

NIAGAWAN Vol 8 No 2 Juli 2019

Diagram 2

Nilai Pengantar Ekonomi Mikro Mahasiswa Prodi Pendidikan Bisnis Angkatan 2017

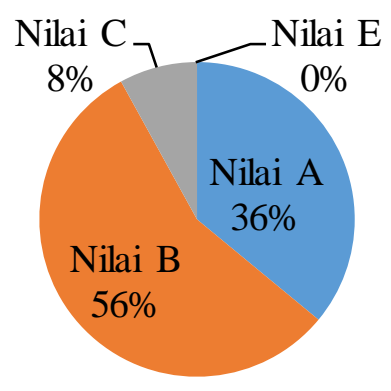

Sumber :Puskom Unimed Diagram 3

Hasil Angket Modernitas Mahasiswa Prodi Pendidikan Bisnis Angkatan 2017

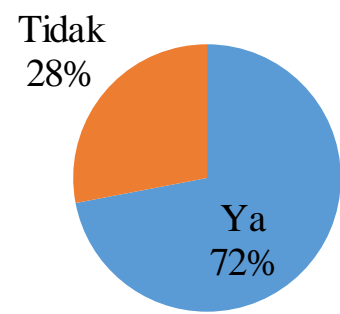

Sumber : Data yang diolah dari angket

Dari diagram di atas, dapat kita lihat bahwa modernitas mahasiswa adalah tinggi, dapat dilihat dari hasil angket di atas mahasiswa yang memilih "Ya" sebanyak $72 \%$ yang artinya mahasiswa merasa telah memiliki modernitas yang tinggi mahasiswa tersebut terbuka dalam menerima perubahan zaman, membuat perencanaan untuk masa depan serta memiliki kepribadian yang rasional dan objektif sedangkan yang memilih "Tidak" sebanyak $28 \%$ yang artinya mahasiswa tidak memiliki modernitas yang tinggi. Dari nilai tersebut, seharusnya mahasiswa memiliki tingkat perilaku konsumtif yang rendah. Tetapi pada kenyataannya,mahasiswa mengabaikan pengetahuan dasar ekonomi yang dimilikinya pada saat melakukan konsumsi suatu barang atau jasa.

\section{TINJAUAN PUSTAKA}

\section{Perilaku Konsumtif serta indikator}

Astuti dan Dewi, (2017 : 38) menyatakan bahwa "perilaku konsumtif adalah kegiatan yang tidak didasarkan pada kebutuhan tetapi pada keinginan dan kepuasan semata. Timbulnya perilaku konsumtif disebabkan oleh faktor internal dan faktor eksternal. Adapun faktor internal yang berpengaruh pada perilaku konsumtif individu adalah motivasi, harga diri, observasi, proses belajar, kepribadian dan konsep diri sedangkan faktor eksternal yang berpengaruh pada perilaku konsumtif individu 
adalah kebudayaan, kelas sosial, kelompok kelompok sosial dan referensi serta keluarga.

\section{Modernitas serta Indikator}

Menurut Rosida (2018:223) bahwa modernitas berakar pada rasionalitas yang tinggi, sebab masyarakat lebih memikirkan objekjektif, afektif dan efisiensi dalam kegiatan-kegiatannya. Indikator dari modernitas antara lain:

1. Bersifat rasional, berfikir futuristik,

2. Menghargai waktu,

3. Bersikap terbuka,

4. Berfikir obyektif,

5. Life satisfaction, dan

6. Life up to date

\section{METODE PENELITIAN}

\section{Lokasi Penelitian}

Penelitian ini dilakukan di Fakultas Ekonomi Universitas Negeri Medan Jalan Williem Iskandar Psr. V - Kotak Pos No. 1589 - Medan 20221 Kecamatan Kota Medan, Sumatera Utara.

\section{Waktu Penelitian}

Penelitian ini dilaksanakan pada semester genap Tahun Ajaran 2018/2019.

\section{Populasi dan Sampel}

Populasi dalam penenlitian ini adalah mahasiswa prodi Pendidikan Bisnis angkatan 2017 Fakultas Ekonomi terdiri dari 3 kelas sebanyak 90 orang, Arikunto (2013:131) menyatakan bahwa" Apabila subjek penelitian kurang dari 100, lebih baik diambil semua sehingga penelitian merupakan penelitian populasi

\section{Teknik Pengumpulan Data}

Observasi, Dokumentasi, Kuisioner/ Angket

\section{Teknik Analisis Data}

Uji Normalitas, Uji Linearitas, Uji

Multikolinearitas

\section{HASIL DAN PEMBAHASAN}

Dari hasil pengolahan data diperoleh model persamaan regresinya sebagai berikut:

$$
\begin{gathered}
Y=\alpha+b_{1} X_{1}+b_{2} X_{2}+e \\
Y=156,609+(-0,615) X_{1}+(-0,625) X_{2}
\end{gathered}
$$

\section{Uji Hipotesis secara Parsial (Uji T)}

1. Untuk variabel literasi ekonomi (X1) diperoleh nilai $-2,457$ dan nilai $t_{\text {tabel }}$ pada $\mathrm{df}=$ $\mathrm{N}-\mathrm{k}(90-3)=87$ pada taraf signifikansi $\alpha \quad 0,05$ ialah 1,662. Hal ini menunjukkan $\mathrm{t}_{\text {hitung }}<\mathrm{t}_{\text {tabel }}$ $(-2,457<1,662)$, dengan taraf signifikansi $\alpha$ $(0,016<0,05)$. Maka H1 diterima sehingga dapat disimpulkan bahwa literasi ekonomi
NIAGAWAN Vol 8 No 2 Juli 2019 secara parsial, ada pengaruh negatif (tidak positif) dan signifikan terhadap perilaku konsumtif mahasiswa.

2. Untuk variabel modernitas (X2) diperoleh nilai $-2,657$ dan nilai $t_{\text {tabel }}$ pada $\mathrm{df}=\mathrm{N}-\mathrm{k}(90$ 3) $=87$ pada taraf signifikansi $\alpha$ 0,05 ialah 1,662. Hal ini menunjukkan $t_{\text {hitung }}<t_{\text {tabel }}(-$ $2,657<1,662)$, dengan taraf signifikansi $\alpha$ $(0,009<0,05)$. Maka H2 diterima sehingga dapat disimpulkan bahwa modernitas secara parsial, ada pengaruh negatif (tidak positif) dan signifikan terhadap perilaku konsumtif mahasiswa.

\section{Uji Hipotesis secara Simultan (Uji F)}

Diperoleh nilai $F_{\text {hitung }}$ adalah sebesar 7,024 dan $F_{\text {tabel }}(\mathrm{dk}=\mathrm{n}-3)$ maka $\mathrm{dk}=90-3=87$, maka $\mathrm{F}_{\text {tabel }}$ ialah 3,10 dengan taraf signifikansi $\alpha$ 0,05 . Sehingga dari hasil perhitungan diperoleh bahwa $F_{\text {hitung }}>F_{\text {tabel }}$ atau 7,024>3,10 dengan nilai signifikansi $\alpha \quad 0,001<0,05$ yang berarti hipotesis 3 diterima. Maka dapat disimpulkan bahwa literasi ekonomi dan modernitas memiliki pengaruh seacar simultan dan signifikan terhadap perilaku konsumtif mahasiswa prodi Pendidikan Bisnis angkatan 2017 Fakultas Ekonomi Universitas Negeri Medan.

\section{Koefisien Determinasi}

Diperoleh nilai koefisien determinasi $(R$ square) sebesar 0,139 atau sebesar $13,9 \%$. Dengan demikian dapat disimpulkan bahwa $13,9 \%$ perilaku konsumtif mahasiswa dipengaruhi oleh literasi ekonomi dan modernitas. Sedangkan $86,1 \%$ dipengaruhi oleh faktor lain dan faktor-faktor lain tersebut tidak diteliti dalam penelitian ini.

\section{Pembahasan}

Berdasarkan anasis deskriptif hasil penelitian mengungkapkan bahwa terkait dengan modernitas mahasiswa dan perilaku konsumtif mahasiswa Pendidikan Bisnis mengungkapkan bahwa apa yang mereka lakukan adalah mengaktualisasikan diri dengan potensi yang dimiliki.Modernitas dan perilaku konsumtif merupan dua hal yang saling berkaitan. modernitas adalah pandangan yang dianut untuk menghadapi masa kini. Selain bersifat pandangan, modernitas juga merupakan sikap hidup. Yaitu sikap hidup yang dianut dalam menghadapi kehidupan masa kini. Kalau berbicara tentang masa kini, maka yang dimaksudkan adalah waktu sekarang dan masa depan. Kini, kemoderenan juga dikaitkan dengan nilai, kesadaran akan semesta. Efektivitas dan efisiansi tidak selalu terkait dengan kecanggihan dan pemborosan.

Mahasiswa adalah manusia modern ini semua merupakan salah satu pernyataan dari seorang tokoh yang bernama Alex Inkeless. Menurut beliau, manusia modern itu bisa 
dinilai dari sikap moralnya. Mahasiswa sebagai seorang yang berpendidikan tinggi dituntut untuk bisa menjadi manusia modern yang memiliki pemikiran yang lebih baik dibandingkan dengan orang yang berpendidikan lebih rendah. Sangat tidak pantas bila mahasiswa memiliki pemikiran yang jauh lebih buruk daripada orang yang memiliki tingkat di bawahnya (Martono 2012). Perilaku juga sangat mempengaruhi kepribadian seorang manusia modern di masa sekarang ini. Tetapi dalam hal ini tidak hanya mahasiswa yang memiliki pemikiran modern. Banyak tingkat yang lebih rendah tetapi memiliki sikap modern.Bukan berarti bahwa semata-mata mahasiswa adalah manusia yang paling moderen dan patut kita contoh tapi mahasiswa pun tidak luput pada kesalahan karena mahasiswa adalah mahluk yang pastinya memiliki kekurangan. Semua itu kembalikan kepada kepercayaan pandangan hidup masing-masing.

Modern bukan saja memiliki hal yang positif tapi pasti selalu saja ada hal negative yang kerap tak terpisahkan dari kelakuan kita. Dalam hal positif, adanya kemajuan teknologi yang dapat membantu mahasiswa untuk mengenal dunia luar dengan cepat tanpa harus mengunjungi tempat itu, modernisasi membuat mahasiswa berpikir lebih maju dan kritis, adanya kebebasan, adanya pertukaran mahasiswa antar Negara. Sebaliknya hal yang negative mempengaruhi mahasiswa, sehingga mereka lupa akan tidak membudayakan kebudayaan lokal yang akan berdampak pada lunturnya budaya lokal dan nilai luhur, adanya penyalahgunaan teknologi dan ilmu pengetahuan yang mereka miliki untuk melakukan hal-hal yang merugikan diri sendiri maupun orang lain.Berdasarkan hasil penelitian yang telah ditemukan dilapangan bahwa modernitas mahasiswa terbentuk dari hidup yang dijalani yang kemudian dari proses itu membetuk suatu pandangan hidup yang mengarahkan segenap prilaku, sikap dan tindakan mereka masing- masing.

Mahasiswa sekarang yang hidup dalam zaman modern memiliki tantangan yang bisa dikatakan berat karena berbagai macam ideologi, sistem yang terbuka tentunya memberikan peluang untuk bisa mengktualisasikan diri dengan baik. Tapi dari sisi lain hal ini bisa menjadi pangser raksasa tak tak terkendalikan yang bisa mengkatarkan pada kerusakan moral mahasiswa.Adapun uraian hasil penelitian Literasi Ekonomi dan modernitas terhadap perilaku konsumtif mahasiswa Prodi Pendidikan Bisnis Universitas Negeri Medan sebagai berikut:
NIAGAWAN Vol 8 No 2 Juli 2019

\section{Proses Terbentuknya Perilaku Konsumtif Mahasiswa Pedidikan Bisnis}

Mahasiswa merupakan anggota masyarakat yang diharapkan mempunyai kemampuan sebagai agent of change dan dapat pula resisten terhdap berbagai macam godaan yang merubah pola pikir mahasiswa saat ini. Kehidupan dikampung asalnya tentu berbeda dengan kehidupan disekitar kampus yang mayoritas telah terpenuhi oleh fasilitas-fasilitas gaya hidup modern. Maka mahasiswa yang sudah terlena dengan berbagai fasilitas- fasilitas tersebut akan menjadi individu yang tidak mampu memilih hal-hal yangbermanfaat bagi dirinya sehingga senantiasa membeli banyak barang baru untuk mengikuti tren perekembangan jaman. Mahasiswa yang seperti itu akan menjadi mahasiswa yang memiliki gaya hidup konsumtif.Sebaliknya mahasiswa yang memiliki pandangan hidup yang ditanamkan sejak dini maka mereka memiliki kemampuan untuk tidak terpengaruh akan tetap konsisten pada tujuannya menjadi seorang mahasiswa yang sebenarnya yaitu menuntut ilmu dalam perkuliahan.

Modernitas dan perilaku konsumtif mahasiswa tidak telepas dari dari adanya arus globalisasi dan modernisasi yang semakin maju saat ini. Kehidupan kota yang penuh dengan sifitas masyarakat kota baik itu politik, sosial mapun ekonomi. Modernitas merupakan hasil dari sebuah proses rasionalisasi struktur yang membangun tingkatan rasionalitas yang tinggi ke dalam lembaga utama masyarakat. Dimulai dari lembaga keluarga, lembaga masyarakat, lembaga pendidikan dan lembaga lainnya. Modernitas yang dipahami sebagai sebuah gerakan dari pola kebudayaan, struktur sosial dan proses tindakan yang tradisional menuju yang bersifat rasional.Pemikiran Weber yang menjelaskan mengenai proses perubahan masyarakat berkaitan erat dengan perkembagan rasionalitas manusia. Menurut Weber (Salim dalam Martono, 2012:47) bentuk rasionalitas manusia meliputi mean (alat) yang menjadi sasaran utama serta ends (tujuan) yang meliputi aspek kultural, sehingga dapat dinyatakan bahwa pada dasarnya orang besar mampu hidup dengan pola pikir yang rasional yang ada pada seperangkat alat yang dimiliki dan kebudayaan yang mendukung kehidupannya. Orang yang rasional akan memilik alat mana yang paling benar untuk mencapai tujuanny dalam pandangan Baudrillard (2015) mengatakan bahwa perilaku boros bukang merupakan sesuatu yang irasional. Konsumsi mempunyai fungsi sosial dan memproduksi makna karena semakin menunjukkan perbedaan nilai. Dalam hal ini, bahwa terbentuknya kepribadian, pandakan hidup, sikap sesorang itu di mulai pada lembaga-lemabaga utama seperti keluarga. Sikap atau perilaku menetukan pula bagaimana 
pola konsumsi yang terjadi. Diketahui bahwa sekarang merupakan zaman modern yang selaga rupa tersedia. Ini merupakan tantangan khusus pada mahsiswa yang dianggap memiliki kemampuan sebagai agen perubahan. Kemampuan mahasiswa dalam memanfaatkan ilmu pengetahuan, kecanggihan teknologi, dan informasi- informasi memberikan dampak yang baik pada mahasiswa tersebut.

Seperti hadirnya teknologi yang dimanfaatkan untuk mempermudah transaksi jual beli, mempromosikan barang-barang dagangan, menawarkan usaha jasa dan sebagainya. Kecanggihan Teknologi tidak sepenuhnya membawa dampak baik pada manusia terkhusus pada mahasiswa yang kadang kala mahasiswa yang masih dalam pencarian jati diri terbawa arus dalam dunia modern yang penuh dengan kerlap- kerlip kehidupan kota. Tersedianya tempat hiburan seperti cafe, resto, mall, dan warkop memberi godaan manis sehingga terbuai prilaku-prilaku yang tidak lagi rasional.

\section{Implikasi Mahasiswa Yang Berperilaku Konsumtif Di Era Modernitas Sekarang Ini \\ Modernitas dan perilaku konsumtif} merupakan sekatuan yang tidak bisa dipisahkan. Perilaku konsumtif ditentukan oleh modernitas seseorang. Dimana hah itu tidak begitu saja muncul tapi melalui proses sosialisasi yang panjang sehingga membentuk suatu sikap, perilaku, dan pandangan hidup untuk menjanali kehidupan modern sekarang ini. Lembaga utama apabila secara struktur telah terbangun dari proses rasionalisasi maka dapat menciptakan manusia-manusia yang rasional pula. Manusia yang dalam tindakannya penuh dengan pertimbangan nilai-nilai yang yang berlaku dan diajarkan dalam masyarakat. Adapun implikasi mahasiswa yang berperilaku konsumtif di era modernitas sekarang ini antara lain sebagai berikut

\section{Motivasi diri}

Dunia modern memberikan peluang dalam memotivasi diri untuk bisa berprestasi dan bersaing dengan yang lainnya. Kemajuan teknologi bisa memberikan manfaatkan apa bila digunakan dengan baik, memanfaatkan waktu luang untuk berpikir meningkatkan situasi sekarang ke arah yang lebih baik.Alex Inkeles (dalam Martono 2012:60) berpendapat bahwa untuk dapat maju dalam suatu masyarakat diperlukan manusai modern, yaitu manusia yang mampu mengembangkan sarana material tersebut supaya menjadi produktif.Artinya bahwa hadirnya arus globalisasi dan modernisasi sebagai kemajuan ilmu pengetahuan teknologi membatu manusia bergerak ke arah yang lebih maju. Tatanan sosial yang lama di reformasi menjadi tatanan yang lebih baik.

\section{Selektif}

Salah satu kriteria mahasiswa dalam mengkonsumsi sesuatu adalah kualitas barang tersebut. itu nampak pada merek-merek tertentu yang melekat pada barang. Pengetahuan akan barang menjadi dasar utama untuk membeli barang tertentu. Banjirnya barang-barang produksi yang masuk ke indonesia menjadikan mahasiswa mampu selektif dalam memilih barang yang diinginkan.

Boros

Pola hidup yang boros dan akan menimbulkan kecemburuan sosial, karena orang akan membeli semua barang yang diinginkan tanpa memikirkan harga barang tersebut murah atau mahal, barang tersebut diperlukan atau tidak, sehingga bagi orang yang tidak mampu mereka tidak akan sanggup untuk mengikuti pola kehidupan yang seperti itu.Menurut Baudrillard (2015) masyarakat dalam hal ini mahasiswa tidak lagi membeli barang karena manfaat yang terkandung di dalamnya, tapi karena dalam kaitan dengan pemaknaan keseluruhan objek (barang). Lebih dari itu Perilaku konsumsi saat ini tidak lagi di pengaruhi pilihan rasional saja, akan tetapi terdapat sistem budaya dan sistem penaknaan sosial yang mampu mengarahkan pilihan individu atas suatu barang. Sama halnya yang dilakukan oleh informan bahwa dirinya harus harus bekerja sambil kuliah untuk menggapai keinginannya.

\section{Relasi Pengaruh Literasi Ekonomi dan Modernitas terhadap Perilaku Konsumtif Mahasiswa Prodi Pendidikan Bisnis Unimed \\ Hasil penelitian ini sejalan dengan} pendapat Rosida Maharani (2018 : 224) modernitas dan literasi ekonomi merupakan dua hal yang sama-sama mengedepankan pemikiran rasionalitas, sehingga ketika siswa mempunyai modernitas dan literasi ekonomi yang baik, seharusnya dapat membantu siswa mempertimbangkan dan membandingkan berbagai hal dari barang yang dibutuhkan atau diinginkan melalui teknologi yang ada dan bedasar pada pemahaman ekonomi yang siswa miliki sehingga siswa dalam berperilaku dapat secara rasional. Modernitas dan perilaku konsumtif merupan dua hal yang saling terkait. modernitas adalah pandangan yang dianut untuk menghadapi masa kini. Selain bersifat pandangan, modernitas juga merupakan sikap hidup. Yaitu sikap hidup yang dianut dalam menghadapi kehidupan masa kini. Kalau berbicara tentang masa kini, maka yang dimaksudkan adalah waktu sekarang dan masa depan. Kini, kemoderenan juga dikaitkan dengan nilai, kesadaran akan semesta. Efektivitas dan efisiansi tidak selalu terkait dengan kecanggihan dan pemborosan. 
Salah satu dasar perilaku konsumtif itu terjadi karena modernitas itu sendiri. Bahwa pribadi yang terdidik dari sejak kecil untuk bersikap konsumtif maka akan menjadi pribadipribadi yang konsumtif, akan menjadi sikap dan pandangan hidup seseorang. Zaman sekarang semakin, barang-barang dan jasa di bangun secara besar-besaran. Sehingga peningkatan konsumeris, pendapatan, dan konsumsi barang dianggap sebagai simbol peran yang penting.Selain itu lingkungan masyarakat juga menjadi jalan untuk mendukung terjadinya perilaku konsumtif dimana masyarakat terbuka dengan perkembangan ilmu pengetahuan dan teknologi terkhusus pada msyarakat kota yang menjadi pusat perdagangan, perekonomina dan pemerintahan yang dilengkapi dengan saran dan prasarana yang lebih baik.Kegitan konsumtif dalam masyarakat modern adalah merupakan sebuah kewajaran. Masyarakat modern diidentikkan dengan semakin membaiknya kemampuan mereka untuk memenuhi kemampuan hidup mereka. Kemampuan dan keterampilan menjadi syarat untuk bisa bersaing dalam kehidupan modern. Selain itu, tidak semua individu memiliki kemampuan untuk mengerjakan suatu. Semua jenis pekerjaan memerlukan keahlian khusus yang harus dipelajarai sehingga kemudian status seseorang ditentukan berdasarkan prestasinya. Keberadaan seseorang individu dalam masyarakat modernakan dihargai sesuai dengan prestasi atau hasil karya yang telah dihasilkannya.

\section{KESIMPULAN DAN SARAN \\ Kesimpulan}

Adapun kesimpulan pada penelitian ini adalah (1) Variabel literasi ekonomi (X1) ada pengaruh negatif (tidak positif) dan signifikan terhadap perilaku konsumtif mahasiswaprodi Pendidikan Bisnis Fakultas Ekonomi Universitas Negeri MedanTahun Pembelajaran 2018/2019 yang ditunjukkan dengan hasil Uji t (parsial), yaitu bahwa thitung <ttabel $(-2,457<1,662)$, dengan taraf signifikansi $\alpha(0,016<0,05)$. (2) Variabel modernitas (X2) ada pengaruh negatif (tidak positif) dan signifikan terhadap perilaku konsumtif mahasiswaprodi Pendidikan Bisnis Fakultas Ekonomi Universitas Negeri Medan.Pembelajaran 2018/2019 yang ditunjukkan dengan hasil Uji t (parsial), yaitu bahwa thitung <ttabel $(-2,657<1,662)$, dengan taraf signifikansi $\alpha(0,009<0,05)$. (3) Hasil dari pengujian secara simultan (Uji F) bahwa literasi
NIAGAWAN Vol 8 No 2 Juli 2019

ekonomi dan modernitas memiliki pengaruh negatif dan signifikan terhadap perilaku konsumtif mahasiswa prodi Pendidikan Bisnis angkatan 2017 Fakultas Ekonomi Universitas Negeri Medan Tahun Pembelajaran 2018/2019 yang ditunjukkan dari hasil Uji F (simultan) yaitu nilai Fhitung >Ftabel atau 7,024> 3,10 dengan nilai signifikansi $\alpha 0,001<0,05$. (4) Hasil uji koefisien determinasi (R2) diperoleh bahwa persentase sumbangan variabel indevenden yaitu literasi ekonomi dan modernitasterhadap perilaku konsumtif mahasiswa sebesar 13,9\% sedangkan sisanya $86,1 \%$ dipengaruhi oleh faktor lain dan faktor-faktor lain diluar penelitian ini.

\section{Saran}

Berdasarkan hasil penelitian yang telah diuraikan dan disimpulkan bahwa diperoleh beberapa saran, yaitu: (1) Mahasiswa diharapkan untuk meningkatkan literasi ekonomi dan modernitasnya agar supaya perilaku konsumtif dapat berkurang. (2) Untuk penelitian selanjutnya diharapkan dapat meneliti variabelvariabel lain yang mempengaruhi perilaku konsumtif diluar variabel yang penulis teliti. Dan selanjutnya diharapkan mrlakukan penelitian yang lebih luas dengan menggunakan populasi dan sampel yang lebih banyak sehingga hasil penelitian ini lebih persentative. (3) Univeritas khususnya Fakultas Ekonomi harus senantiasa meningkatkan literasi ekonomi melalui pemberian tugas praktek langsung ke lapangan untuk meningkatkan pemahaman literasi ekonominya dan memiliki pengetahuna yang baik dan melakukan konsumsi yang rasional.

\section{REFERENSI}

Angra,Saftia \& Wulandari. (2018).'Pengaruh Literasi Ekonomi Dan Gaya Hidup Terhadap Perilaku Konsumtif Mahasiswi Pendidikan Ekonomi STKIP YPM Bangko". Volume 2, Nomor 1, April 2018 ISSN : 2597-8853 141

Arikunto, Suharsimi. 2012. Prosedur Penelitian Suatu Pendekatan. Jakarta: Rineka Cipta.

Baudrillar, Jean. 2015. Masyarakat Konsumsi. Bantul: kreasi wacana

Dewayani, Sofie.2017. Mneghidupkan Literasi Di Ruang Kelas. Yogyakarta:PT KANISIUS.

Endang Sri Rahayu \& Pratiwi Suciningrum.(2015).Pengaruh Status Sosial Ekonomi Orang Tua dan Pengetahuan Dasar Ekonomi Terhadap 
Perilaku Konsumsi Kelas XI Sma Pusaka 1 Jakarta. Volume.3, No. 1

Hardiman, F.Budi.2007. Melampaui Positivisme dan Modernitas "Diskursus Filosofis tentang Metode Ilmiah dan Problem Modernitas".Yogyakarta. Kanisius.

Kanserina, Dias. (2015). "Pengaruh Literasi Ekonomi Dan Gaya Hidup Terhadap Perilaku Konsumtif Mahasiswa Jurusan Pendidikan Ekonomi Undiksha 2015". Vol: 5 Nomor: 1 Tahun: 2015

Kadeni \& Srijani, Ninik. (2018). "Pengaruh Media Sosial Dan Teman Sebaya Terhadap Perilaku Konsumtif Mahasiswa". Equilibrium, Volume 6, Nomor 1, Januari 2018

Kamus Besar Bahasa Indonesia (online). Kbbi.kemdikbud.go.id/entri/konsumsi/.

Kusniawati \& Kusniawan.(2016).” Pengaruh Status Sosial Ekonomi Orang Tua Dan Literasi Ekonomi Terhadap Perilaku Konsumsi Siswa Kelas X IPS Di SMA Negeri 2 Tuban". Volume 4 No 3 Edisi Yudisium 2016

Maharani, Rosida .(2018). "Pengaruh Modernitas Dan Literasi Ekonomi Terhadap Perilaku Konsumsi Siswa Kelas XI IIS Di Sma Negeri 1 Talun". Volume 6 Nomor 3 Tahun 2018: 222 - 229

Muhammad, Syahril. 2013. Masyarakat Ternate Pergaulatan Tradisi dan Modernitas. Yogyakarta:Penerbit Ombak.

Murniatiningsih, Endah.(2017). Pengaruh Literasi Ekonomi Siswa, Hasil Belajar Ekonomi dan Teman Sebaya Terhadap Perilaku Konsumsi Siswa SMP Negeri di Surabaya Barat. Volume 5 No. 1

Martono, Nanang. 2012. Sosiologi Perubahan Sosial: Perspektif Klasi, Modern, Posmodern, dan Poskolonial. Jakarta: Raja Grafindo Persada.

Nurita Dewi, Rusdarti, Sunarto. (2017). Pengaruh Lingkungan Keluarga, Teman Sebaya, Pengendalian Diri dan Literasi Keuangan Terhadap Perilaku Konsumtif Mahasiswa. Volume 6, No. 1

Okky Dikria \& Sri Umi Minarti W. (2016). Pengaruh Literasi Keuangan dan Pengendalian Diri Terhadap Perilaku Konsumtif Mahasiswa Fakultas Ekonomi Universitas Negeri Malang. Volume.9, No.

Prabu, Anwar. 2012. Perilaku Konsumen. Bandung: PT Refika Aditama

Pracoyo, T.K. \& Pracoyo, A. 2006. Aspek Dasar Ekonomi Mikro. Jakarta: Grasindo.

Rahayu, Anita. Asriati, Nuraini.\& Syahrudin, Husni.(2017).’Pengaruh Literasi Ekonomi Dan Modernitas Terhadap Perilaku Konsumsi Siswa Kelas XI IPS SMAN 1 Segedong". Vol 6, No 10 (2017): Oktober 2017
NIAGAWAN Vol 8 No 2 Juli 2019

Risnawati, dkk. (2018).'Pengaruh Pendidikan Ekonomi Keluarga, Gaya Hidup, Modernitas Individu, dan Literasi Ekonomi terhadap Perilaku Konsumtif Siswa". Volume: 3 Nomor: 4 Bulan April Tahun 2018. EISSN: 2502-471X.

Rizky.(2016).’Pengaruh Pengelolaan Uang Saku, Modernitas, Kecerdasan Emosional, Dan Pemahaman Dasar Ekonomi Terhadap Rasionalitas Perilaku Konsumsi Siswa Kelas $\mathrm{X}$ IIS MAN 1 Malang ".Volume 9, Nomor 1, 2016

Siti Hardianti, Achmadi, Husni Syahrudin.(2018). "The Effect of Parent's Social Economic Status and Economic Literacy on the Consumption Decision of Economic Education Students FKIP Untan".Vol.5; Issue: 12; December 2018

Siti Nurjanah, Risca Zaqia Ilma, Suparno.(2018)."Effect of Economic Literacy and Conformity on Student Consumptive Behaviour". Vol. 13, No.2. DOI: 10.15294/dp.v13i2.18330

Solihat, Nur \& Arnasik, Syamsudin. (2018).'Pengaruh Literasi Ekonomi Terhadap Perilaku Konsumtif Mahasiswa Jurusan Pendidikan Ekonomi Universitas Siliwangi".Volume II Nomor 1, Mei 2018.ISSN Online : 2549-2284.

Sugiyono. 2013. Metode Penelitian Pendidikan : Pendekatan Kuantitatif, Kualitatif dan $R \& D$. Alfabeta: Bandung.

Turner, Bryan.S. 2008. Teori-Teori Sosiologi Modernitas Posmodernitas. Yogyakarta: Pustaka Pelajar.

Wijayanti, Astuti \& Puri, Dewi.(2017). "Hubungan Antara Konsep Diri dengan Perilaku Konsumtif Remaja di Kota Denpasar". Vol. 4, No.1 